\title{
STRATEGI PENGEMBANGAN AGROEKOWISATA JAMBU AIR DI KECAMATAN CAMPLONG KABUPATEN SAMPANG
}

\author{
KHOTIBUL UMAM ${ }^{\mathbf{*}}$, SITI KHOTIJAH ${ }^{\mathbf{1}}$, MOHAMMAD ZAINURI ${ }^{\mathbf{1}}$ \\ ${ }^{1}$ Fakultas Ekonomi dan Bisnis Islam Institut Agama Islam Negeri Madura \\ Jalan Raya Panglegur Km.4 Pamekasan 69371 - Jawa Timur Indonesia \\ *E-mail: Umamsibly@gmail.com
}

\begin{abstract}
ABSTRAK
Penelitian ini bertujuan untuk menganalisis strategi pengembangan agroekowisata Jambu Air di wilayah Kecamatan Camplong Sampang. Metode penelitian dalam penelitian ini menggunakan pendekatan kualitatif desktiptif dengan menghadirkan alalisis SWOT untuk memetakan berbagai macam startegi yang dapat digunakan peneliti dalam mengembangkan agreoekowisata jambu air. Hasil dari penelitian ini menyimpulkan bahwa diperlukan minimal empat langkah strategis sebagai upaya dalam mengembangkan agroekowisata Jambu Air di wilayah Kecamatan Camplong Sampang yang meliputi strategi dalam pengembangan promosi, strategi pengembangan sarana dan prasarana, strategi pengembangan sumberdaya alam dan strategi pengembangan kemitraan/kerja sama dengan pihak terkait, baik dengan pemerintah, masyarakat, maupun sentra penjual buah dalam memasarkan buah jambu air beserta hasil olahannya kepada masyarakat luas. Dampak dari strategi tersebut tidak hanya dapat meningkatkan kesejahteraan masyarakat di sekitar agroekowisata jambu air, namun juga dapat meningkatkan literasi wisatawan mengenai budi daya tanaman jambu air yang sudah menjadi icon kebanggaan Kabupaten Sampang
\end{abstract}

Kata kunci: Strategi, Agroekowisata, Jambu air.

\section{ABSTRACT}

This study aims to analyze the development strategy of Guava Water Agro- ecotourism in Camplong Sampang Subdistrict. The research method in this study used a desktiptif qualitative approach by presenting a SWOT analysis to map various types of strategies that can be used by researchers in developing water guava agro-tourism. The results of this study conclude that a minimum of four strategic steps are needed as an effort to develop Guava Water Agro-tourism in Camplong Sampang Subdistrict which includes strategies in promotion promotion, infrastructure and development strategies, strategies for developing natural resources and strategies the development of partnerships / cooperation with related parties, both with the government, the community, and the fruit seller centers in marketing water guava fruits and their processed products to the general public. The impact of this strategy can not only improve the welfare of the community around guava agrotourism, but also can improve tourist literacy regarding cultivation of guava plants that have become the pride icon of Sampang Regency.

Keywords: Strategy, Agro-ecotourism, Guava water.

\section{PENDAHULUAN}

Pariwisata merupakan salah satu faktor pendorong perekonomian masyarakat. Tata kelola dalam sektor pariwisata haruslah dilakukan secara bijaksana, karena sektor pariwisata yang tidak dikelola secara benar akan berpotensi menimbulkan masalah atau dampak negatif terhadap kehidupan sosial, ekonomi, dan lingkungan. Menurut Retnowati (2004) seperti yang dikutip oleh Hidayat (2017), mengatakan bahwa adanya aktivitas agroekowisata (pariwisata) diharapkan dapat memberikan manfaat 
kepada masyarakat setempat dengan pembukaan lapangan kerja, kesempatan berusaha, dan pendanaan yang di serap kembali dalam bentuk proyek-proyek pembangunan daerah.

UU Republik Indonesia Nomor 10 Tahun 2009 tentang Pariwisata, mendefinisikan wisata sebagai kegiatan perjalanan yang dilakukan oleh seseorang atau kelompok orang dengan mengunjungi tempat tertentu untuk tujuan rekreasi, pengembangan pribadi, atau mempelajari keunikan daya tarik wisata yang di kunjungi dalam waktu sementara. Selanjutnya pariwisata adalah kegiatan wisata yang didukung oleh berbagai fasilitas serta layanan yang disediakan masyarakat, pengusaha, pemerintah, dan pemerintah daerah (I Ketut Suwena and I Gst Ngr Widyatmaja, 2010).

Kawasan agroekowisata jambu air merupakan sentra produksi buah jambu air yang terdapat di Kebupaten Sampang Madura. Hasil dari perkebunan jambu air Camplong tersebut merupakan salah satu buah unggulan daerah Jawa Timur sesuai dengan SK Mentan No. 40/Kpts/TP.240/1/97. Menurut Iswahyudi, Emmy Darmayanti and Sutrisno (2015) luas areal tanaman jambu air jenis Camplong ini mencapai 780 hektar dengan jumlah tanaman sekitar 160.000 pohon dan memiliki 3 kali musim penen dalam setahun yakni pada bulan Februari, Juni, dan Oktober. Menurut data Badan Pusat Statistik Indonesia, jumlah produksi jambu air Camplong pada tahun 2010, 2011, 2012 dan 2013 secara berturut-turut adalah 8.067.9 ton, 2.549.4 ton, 3.694.7 ton dan 2.392 ton. Adapun jumlah produksi jambu air pada tahun 2015 menjadi 1586 ton

Pengembangan

Kawasan Agroekowisata memiliki maksud untuk membentuk, menyelaraskan dan mengendalikan pembangunan fisik, budaya dan kegiatanpariwisata serta pemberdayaan masyarakat dikawasan mempura sebagai kawasan agrowisata.Sedangkan tujuannya adalah : (1) Membuat konsep awal penataan kawasan untuk pengembangan kawasan agrowisata yang memiliki daya saing, daya tarik investasi dan tetapmemiliki karakter budaya melayu. (2) Menata kawasan dengan mempertimbangkan aspekarsitektural, fungsional dan pola penataaan lingkungan yang sesuai dengan kebijakankawasan. (3) Mengimplementasikan konsep penataan kawasan dalam perencanaan tapak, tataletak, sirkulasi, lensekap dan pola lingkungan (Jojok Dwirido Tjahjono et al, 2018).

Berdasarkan latar belakang diatas, dapat diketahui bahwa agroekowisata 
jambu air memiliki potensi wisata yang sangat besar dalam memberdayakan masyarakat sekaligus meningkatkan pendapatan asli daerah sampang mengingat lahannya yang luas dan merupakan salah satu produk buah unggulan. Oleh karena itu peneliti menganggap penting untuk mengadakan kajian lebih mendalam dalam menganalsis stategi apasajakah yang dapat dilakukan peneliti untuk mengembangkan potensi agroekowisata jambu air di Kecamatan Camplong Sampang dengan menghadirkan kekuatan, kelemahan, peluang dan ancaman (SWOT) dari agroekowisata jambu air tersebut.

\section{METODE PENELITIAN}

Dalam penulisan karya ilmiah, metode merupakan cara bertindak agar suatu penelitian dapat terlaksana secara rasional, terarah, objektif, dan tercapai hasil yang optimal (Beker, 1992). Adapun metode penelitian yang dilakukan dalam penelitian ini adalah sebagai berikut:

\section{Jenis Penelitian}

Jenis penelitian yang digunakan dalam penelitian ini adalah jenis penelitian kualitatif-deskriptif yang bertujuan untuk menjelaskan secara menyeluruh, luas dan mendalam mengenai objek penelitian sehingga dapat menghadirkan kesimpulan yang relevan.

\section{Objek penelitian}

Objek penelitian dalam penelitian ini adalah strategi pengembangan agroekowisata jambu air di Kecamatan

\section{Camplong Sampang}

\section{Tempat dan Waktu}

Penelitian ini dilakukan di kawasan kebun jambu air Kecamatan Camplong Sampang yang dilaksanakan pada tahun 2019.

\section{Teknik Pengumpulan Data}

Adapun teknik pengumpulan data yang digunakan dalam penelitian ini adalah sebagai berikut:

a. Wawancara

Peneliti akan bertanya dan mewawancarai langsung para responden mengenai pokok-pokok permasalahan baik kepada petani buah, masyarakat sekita, tokoh masyarakat dan isntansi pemerintah yang meliputi dinas pariwisata, dinas kehutanan, dan lainnya.

b. Observasi lapangan

Peneliti akan turun langsung melakuka observasi lapangan untuk mengecek keabsahan data yang diterima melalui peroses wawancara

c. Dokumentasi

Peneliti mengumpulkan dan mendokumentasikan sumber-sumber di lapangan yang berkaitan dengan 
permasalahan yang sedang diteliti atau dari hasil publikasi lembaga-lembaga instansi pemerintah seperti dinas perhutanan dan pariwisata.

d. Kepustakaan

Peneliti menelaah buku-buku, jurnal, peraturan-peraturan dan teori yang dapat dijadikannya referensi dalam penulisan penelitian ini.

5. Metode analisis data

Metode analisis data yang digunakan dalam penelitian ini menggunakan adalah metode analisis kualitatif deskriptif dengan menganalisis data yang bertujuan untuk mengembangkan, menjalankan hasil yang diperoleh dari penelitian terhadap potensi objek wisata. Proses analisis data dalam penelitian ini dimulai dari menelaah data yang sudah dikumpulkan baik dari hasil wawancara, observasi lapangan, dokumentasi dan kepustakaan yang sudah dicatat dalam catatan penelitian. Setelah itu peneliti mereduksi data dengan merangkumnya dengan memilih hal-hal yang dianggap penting untuk mempermudah analisis data. Setelah itu peneliti keabsahan data dengan menggunakan triangulasi data baik yang diperoleh melalui peroses wawancara, observasi, dokumnetasi dan lainnya. Setelah melakukan triangulasi data, peneliti kemudian melakukan penafsiran data sekaligus mengambil kesimpulan berdasarkan teori yang sudah dibangun sebelumnya

\section{HASIL DAN PEMBAHASAN}

\section{Gambaran Agroekowisata Jambu} Air

Agrowisata merupakan agenda wisata yang berisi perjalanan yang memanfaatkan lahan pertanian mulai dari proses produksi hingga diperoleh produk pertanian dalam berbagai sistem dan skala dengan tujuan memperluas pengetahuan (Haidawati et al, 2016). Sedangkan ekowisata merupakan perjalanan wisata ke suatu lingkungan baik alam yang alami maupun buatan serta budaya yang ada yang bersifat informatif dan partisipasi yang bertujuan untuk menjamin kelestarian alam dan sosial-badaya. Ekowisata menitik beratkan pada tiga hal utama yaitu: keberlangsungan alam dan ekologi, memberikan manfaat ekonomi, dan secara psikologi dapat diterima dalam kehidupan sosial masyarakat. Jadi, kegiatan ekonomi secara langsung memberi akses pada semua orang untuk melihat, mengetahui, dan menikmati pemandangan alam, intelektual dan budaya masyarakat lokal (Satria, 2009). Dalam literatur lainnya, ekowisata dapat diartikan sebagai 
perjalanan ke tempat alami yang melestarikan lingkungan dan meningkatkan kesejahteraan masyarakat lokal (Sayyed, Mansoori and Jaybhaye, 2013).

Dari penjelasan agrowisata dan ekowisata tersebut, maka dapat disimpulkan bahwa agroekowisata adalah suatu bentuk pariwisata yang memanfaatkan budaya petani sebagai daya tarik wisata. Agroekowisata tidak hanya menawarkan rekreasi, namun juga dapat meningkatkan pengetahuan pertanian pengunjungnya dan mengurangi arus urbanisasi dengan memandirikan dan memajukan perekonomian setempat terutama petani. Menurut Spillane (1994) untuk mengembangkan suatu kawasan menjadi kawasan pariwisata (termasuk juga agroekowisata) terdapat 5 unsur yang harus dipenuhi, yaitu aktraksi, fasilitas, infrastruktur, trasportasi, dan keramahan pelayanan.

Kebun Jambu air Camplong terdapat di Kebupaten Sampang Madura. Perkebunan jambu air Camplong tersebut merupakan salah satu buah unggulan daerah Jawa Timur sesuai dengan SK Mentan No. 40/Kpts/TP.240/1/97. Menurut iswahyudi et al (2015) luas areal tanaman jambu air jenis Camplong ini mencapai 780 hektar dengan jumlah tanaman sekitar
160.000 pohon dan memiliki 3 kali musim penen dalam setahun yakni pada bulan Februari, Juni, dan Oktober. Menurut data Badan Pusat Statistik Indonesia, jumlah produksi jambu air Camplong pada tahun 2010, 2011, 2012 dan 2013 secara berturut-turut adalah 8.067.9 ton, 2.549.4 ton, 3.694.7 ton dan 2.392 ton. Adapun jumlah produksi jambu air pada tahun 2015 menjadi 1586 ton

Keberadaan agroekowisata kebun jambu air ini diharapkan dapat menjadi wahana wisata yang dapat menarik masyarakat luas terutama memberikan literasi pengetahuan dalam budidaya tanaman jambu air. Selain itu, pengembangan agroekowisata ini juga di harapkan dapat menarik masyarakat setempat untuk berwirausaha terutama dalam mengelola hasil panen jambu air sebagai makanan atau cemilan khas Camplong sekaligus sentra penjualan souvenir, kerajinan dan cindera mata masyarakat setempat.

\section{Potensi-Potensi Agroekowisata}

\section{Jambu Air}

Potensi-potensi yang terdapat dalam ekowisata jambur air ini terdiri adalah sebagai berikut: 


\section{a. Wisata satu-satunya di Pulau}

\section{Madura}

Agroekowisata kebun jambu air Kecamatan Camplong adalah satusatunya wisata jambu air yang ada di Kabupaten Sampang bahkan satusatunya wisata jambu air yang ada di Pulau Madura sehingga mempunyai potensi yang bagus memikat banyak wisatawan baru. Peneliti ingin mengembangkan agroekowisata kebun jambu air Kecamatan Camplong menjadi wisata yang memberikan pengaruh besar terhadap masyarakat luas, baik dari segi ekonomi melalui pengolahan hasil panen, maupun dari segi literasi dapat membudidayakan tanaman jambu air.

\section{b. Terdapat makanan has olahan jambu} air yang dapat dipejualbelikan

disekitar Agroekowisata jambu air.

Dinas koperasi Usaha Mikro dan Tenaga Kerja (Diskumnaker) telah mengadakan pelatihan pengelolaan jambu air Camplong ini. Pelatihan tersebut pematerinya adalah Nadzirul Layli S.TP guru SMK II Sampang selama sukses dalam mengembankan olahan jambu air menjadi Dodol buah Jambu Air, Esense daun Jambu Air serta Teh daun Jambu Air (Radarbangsa: 2018). Produk hasil olahan tersebut diharapakan dapat menjadi alternatif usaha yang dapat dikembangkan masyarakat dalam meningkatkan perekonomiannya maupun dalam mendorong terciptanya produk unggulan baru lainnya.

\section{Analisi SWOT Agroekowisata}

\section{Jambu Air Kecamatan Camplong}

Pengembangan agroekowisata pada kawasan jambu air di Camplong di rumuskan melalui analis SWOT sebagi berikut:

a. Kekuatan (Strength)

Kekuatan yang di maksud adalah potensi yang dimiliki untuk dikembangkan dimasa yang akan datang. Adapun kekuatan yang mendukung untuk pengembangan agroekowisata sebagai berikut:

1) Tempat kebun sangat strategis. kebun jambu air di Camplong tidak jauh dari ralan raya (sekitar 200m dari jalan raya) sehingga pewisata mudah menggakses ke tempat agroekowisata jambu air.

2) Memiliki konsep agribisnis yang menarik, yaitu “ petik sendiri buah jambu air dari lahan yang ada”.

3) Satu-satunya agroekowisata jambu air yang ada di pulau Madura

4) Sudah ada kelompok asosiasi kebun jambu air. 
5) Sudah menjadi icon kebupaten Sampang

6) Memiliki produk makanan dari hasil olahan jambu air

b. Kelemahan (Weakness)

Kelemahan yang di maksud dalam hal ini adalah kekurangan atau hambatan dalam penegmbangan kawasan wisata. Adapun kelemahannya sebagai berikut:

1) Fasilitas umum kurang memadai seperti tempat parkir, toilet, peralatan memitik buah, tempat bermain anak, dan lain seabagainya

2) Jalan menuju kebun jambu air masih dalam tahap pembangunan.

3) Siklus masa panen jambu air mengikuti sistem musiman, jadi kadang kala kurang dapat di dpredeksi tergantung cuaca.

4) Sarana tranportasi yang masih minim untuk menuju kebun jambu air.

5) Kurangnya manajemen SDM yang memadai

c. Peluang (Opportunity)

Peluang yang di maksud dalam hal ini adalah faktor pendukung dari pengembangan agroekowisata di kawasan kecamatan Camplong. Adapun peluangnya sebagai berikut:
1) Dukungan dari masyarakat dan tokoh-tokoh masyarakat sekitar kawasan kebun jambu air, terutama dalam pengembangan kawasan wisata dengan harapan mereka dapat ikut dilibatkan mulai dari perencaaan samapai pemanfaatnan hasil.

2) Adanya home industri yang berdiri seperti home industri makanan khas Camplong dan makanan yang terbuat dari bahan pokok jambu air.

3) Menjadi wadah edukasi bagi generasi selanjutnya

4) Sudah ada kerjasamadengan pemerintah melalui program pengolahan hasil pertanian

d. Ancaman (Treath)

Ancaman yang dimaksud dalam hal ini adalah faktor-faktor yang menghambat untuk pengembangan di masa yang akan datang. Adapaun ancamannya adalah:

1) Adanya tempat wisata lain yang jaraknya tidak terlalu jauh walaupun jenis wisata yang ditawarkan berbeda namun sangat menarik para wisatawan untuk berkunjung seprti wisata pantai Camplong.

2) Belum adanya MoU (Memorandum of Understanding) yang jelas dalam 
budidaya dan pemasaran pasca panen.

3) Jika tidak ada inovasi maka akan kalah dengan persaingan di luar

\section{Strategi Pengembangan}

\section{Agroekowisata Jambu Air}

Berdasarkan hasil analisis tersebut SWOT tersebut, peneliti merumuskan empat strategi yang dapat digunakan dalam mengembangkan agroekowisata jambu air sampang, yaitu:

\section{a. Strategi Pengembangan promosi secara offline dan online}

Promosi merupakan salah satu upaya memperkenalkan wisata jambu air kepada masyarakat. Agar peroses promosi dapat berjalan dengan efektif maka diperlukan adanya bauran promosi, yaitu kombinasi yang optimal bagi berbagai jenis kegiatan atau pemilihan jenis kegiatan promosi yang paling efektif dalam meningkatkan penjualan. Menurut Kotler (2006) ada lima jenis kegiatan promosi, antara lain: periklanan, personal selling, publisitas, promosi penjualan, dan pemasaran langsung. Di era Revolusi industri 0.4 ini peneliti dalam mempromosikan agroekowisata merekomendasikan menggunakan metode offline dan online. Dalam mempromosikan secara offline peneliti menggunakan pemikiran Kotler sebagimana yang sudah disebutkan di atas yang meliputi periklanan, personal selling, publisitas, promosi penjualan, dan pemasaran langsung . Sedangkan kegiatan promoi secara online peneliti merekomendasikan media jejaring sosial media berbasis internet seperti whatsup, facebook, instagram, website, jual beli online dan lain sebagianyaagar dapat menjangkau seluruh pangsa pasar yang lebih luas baik, lokal, nasional, maupun interbasional.

\section{b. Strategi pengembangan sarana prasarana}

Pengembangan pariwisata di Kecamatan Camplong harus sejalan dengan fasilitas sarana prasarana dan infrastruktur yang ada di Kecamatan Camplong agar dapat memenuhi kebutuhan dan kenyamanan wisatawan. Suwantoro (2004) seperti juga yang dikutip oleh Saga Ardian Gurindawangsa, Topowijono and Supriono (2017) menyatakan bahwa sarana wisata merupakan perlengkapan sarana di tempat tujuan wisata yang diperlukan untuk melayani kebutuhan wisatawan dalam menikmati perjalanan wisatanya.Saat ini pengembangan dan pembangunan infrastruktur di kawana wisata jambu air dilakukan secara bertahap. Program pembanguna tahun ini meliputi pembangunan taman dekat kebun jambu 
air, trotoar jalan, dan dan pengembangan jalan ke kebun. Selain itu, saat ini juga sedang dilkukan perbaikan jalan dan pembuatan Musolla, toilet, dan ruangan tempat pembelajaran jambu air mulai dari peroses menyangkok jambu air, pengolahan hasil jambu air, dan lain sebagainya sehingga para wisatawan dapat belajar mengenai tata cara budidaya tanaman jambu air di ruangan tersebut.

$$
\text { Kedepannya agroekowisata }
$$

wilayah Camplong ini perlu menambahkan membangun homestay sekaligus menyediakan sarana transprortasi wisatawan yang berupa mobil dobel gardan yang penyediaan dan pengelolaannya dapat bekerja sama dengan masyarakat setempat. Selain itu, kawasan agroekowisata juga diharapkan dapat meningkatkan sarana penunjang wisata lainnya seperti resto area, ayunan di setiap pepohonan jambu air, tangga menuju balkon yang dibuat di pinggiran kebun jambu air, tempat parkir yang luas dan lain sebagainya. Masyarkat diharapkan ikut andil dalam mengembangkan prasarana dengan menyediakan jasa foto, terdapat home industry, jajanan dan penjualan souvenir di sekitar kebun jambu air.

\section{c. Strategi pengembangan sumber daya manusia}

Sumber daya manusia yang profesional merupakan motor penggerak dalam pengembangan dan pengelolaan agroekowisata jambu air ini. Minimnya pengelola agroekowisata yang handal dapat menjadi kendala dalam pengembangan agroekowisata jambu air. Oleh karena itu peneliti mengharap peran pemerintah dan masyarakat untuk lebih intens dalam mengadakan pelatihan budidaya jambu air mulai dari pra panen hingga pasca panen dengan mendatangkan tim ahli wisatawan baik dari ITB (institut Pertanian Bogor), UGM (univesitas Gajah Mada), dan universitas lainya yang memiliki keilmuan tentang pariwisata terutama dibidang agroekowisara jambu air.

Sifat dari pelatihan ini dapat dilakukan baik melalui media tatap muka secara offline dengan menghadirkan tim ahli tersebut maupum melalui media online seperti Whatsup grup, facebook, dan video call confrence yang pematerinya dapat berupai tokoh masyarakat, dosen, praktisi dan akademisi yang berpengalaman dalam ilmu agroekowisata. Hasil dari notulensi kajian online ini nantinya dapat di upload di grup whatsup, facebook maupun ke website agroekowisata kebun jambu air 
Kecamatan Camplong. Adapun hasil dari kajian offline yang telah dilakukan nantinya dapat dijadikan artikel yang dikumpulkan untuk dibukukan sekaligus dimuat di grup whatsup, facebook maupun ke website agroekowisata kebun jambu air Kecamatan Camplong. Keberadaan pelatihan tersebut diharapkan dapat mendorong masyarakat pembudidaya jambu air untuk terus berinovasi dalam mengelola dan memajukan potensi pengembangan agroekowisata jambu air tersebut.

\section{d. Strategi pengembangan}

\section{kemitraan/kerja sama dengan pihak terkait}

Peneliti menyepakati pendapat Ardian., dkk (2017) yang menyatakan bahwa Pemerintah berfungsi sebagi pembuat peraturan dan pendukung pelaksanan pembangunan pariwisata. Sedangkan masyarakat berperan sebagai tuan rumah dan pelaku pembangunan pariwisata. Kemitraan (kerja sama) antar sesama petani jambu air dalam meningkatkan kualitas penjualan dan pengolahan hasil panen adalah dengan bergabung menjadi anggota paguyuban asosiasi kelompok petani jambu air. Masyarakat yang awalnya hanya menjual jambu air tanpa diolah terlebih dahulu, diharapkan dengan adanya kemitraan masyarakat melalui asosiasi kelompok jambu air dapat mengingkatkan harga jual panen dengan mengkreasikan olahan jambu air menjadi dodol jambu air, ice cream jambu air, kerupuk jambu air serta menfaatkan pucuk daun jambu air menjadi teh pucuk jambu air melalui pelatihan serta regulasi yang memudahkan petani

Adapun untuk kerjasama petani jambu air dengan pemerintah (Dinas Kehutanan dan Pariwisata), diharapkan dapat membantu pengembangan agroekowisata dengan kebijakan dan program-programnya dalam pengembangan agroekowisata di Kecamatan Camplong terutama dalam membudidayakan tanaman jambu air baik yang meliputi pelatihan sebelum panen, pemupukan, pengolaham hasil panen dan penjualan kemitraan (kerja sama) dengan perusahaan waralaba seperti Alfamidi, Carrefour, Circle-K, minimarket, pasar buah dan sentral penjualan buah lainnya. Selain itu, pemerintah diharapkan terus mendukung dalam pengembangan infrastruktur dan sarana prasarana lainnya yang dapat mendukung tumbuh kembangnya agroekowisata jambu air di Kecamatan Camplong. 


\section{Dampak Strategi Pengembangan}

\section{Agroekowisata Jambu Air}

Dampak signifikan dari empat strategi pengembangan agroekowisata jambu air tersebut diharapkan dapat memberikan pengaruh positif terhadap perekonomian dan sosial masyarakat

\section{a. Dampak ekonomi}

Dampak ekonomi yang dirasakan oleh masyarakat adalah peningkatan jumlah pendapatan masyarakat sekaligus sebagai alternatif-alternatif penghasilan masyarakat dengan bekerja dibidang pariwisata seperti menjadi guide ataupun bekerja sama dalam melayani para wisatawan seperti pembuatan homestay ataupun menjalankan agroekowisata. Selain itu, pengembangan agroekowisata jambu air ini diharapkan dapat memotivasi masyarakat untuk meningkatkan jiwa kewirausahaannya dengan menjual hasil olahan jambu air dan souvenir atau cindera mata oleh-oleh khas kecamatan Camplong. Dengan adanya dampak ekonomi yang positif ini dihapakan dapat mendorong perekonomian masyarakat dan pihak-pihak terkait di sekitar kebun jambu air Kecamatan Camplong menjadil lebih sejahtera.

\section{b. Dampak sosial}

Dampak sosial yang terjadi melaui strategi pengembangan agroekowisata jambu air tersebut adalah sinergi antara pemerintah dan masyarakat, dan wisatawan dalam mengembangkan egroekowisata tersebut. Dimana pemerintah berhasil meningkatkat kesejateraan dan mengedukasi masyarakatnya melalui pelatihan budidaya dan pengolahan hasil panen jambu air. Adapun bagi para wisatawan, mereka dapat meningkatkan literasi penegtahuannya tentang budidaya agroekowisata jambu air dengan mendatangi langsung agroekowisata jambu air tersebut.

\section{KESIMPULAN}

Menjadikan agroekowisata kebun jambu air Kecamatan Camplong Sampang sebagai sarana untuk mensejahterakan dan mengedukasi masyarakat merupakan suatu keniscayaan. Berdasarkan hasil dari analisi SWOT yang telah dilakukan, kekuatan dan peluang agroekowisata ini memiliki nilai kualitatif yang lebih tinggi apabila disandingkan dengan ancaman dan kekurangannya. Peneliti menitikberatkan penguatan promosi online untuk menjangkau suluruh wisatawan potensial dan meningkatkan pelatihan pengelolaan budidaya jambu air (baik offline maupun online) sebagai penguatan sumber daya manusia yang agroekoswisata jambu air terutama dalam menghadapi era revolusi 
industri 4.0. Selain itu pengembangan infrastuktur dan sumber daya manusia harus mendapatkan perhatian serius dari seluruh stakeholder dan pemerintah. Peneliti sangat berharap agar pemerintah dan masyarakat setempat dapat bersinergi dalam pembangunan infrastruktur sarana dan prasarana yang mendukung pengembangan agroekowisata jambu air, seperti jalan, taman bermain, ruang eduksi dan pelatihan lainnya. Keberdaan agroekowisata ini diharapkan tidak hanya sebagai sarana dalam mensejahterahkan prekonomian masyarakat semata, namun juga dapat menambah literasi dan pengetahuan masyarakat tentang budidaya jambu air yang secara tidak langsung ikut mempromosikan agroswisata yang sudah menjadi icon kebanggaan Kabupaten Sampang.

\section{DAFTAR PUSTAKA}

Anton Beker dan Ahmad Charis Zubair. (1992). Metodelogi Penelitian Filsafat Yogyakarta: Kanisius.

Badan Pusat Statistik kabupaten Sampang. (2017). Kabupaten Sampang Dalam Angka 2017, Sampang: BPS Kabupaten Sampang

Badan Pusat Statistik Kabupaten Sampang. (2013). Produksi Buah-buahan Menurut Kecamatan dan Jenis Buah di Kabupaten Sampang 2013, diakses dari https://sampangkab.bps.go.id/staticta ble/2014/01/03/140/produksi-buahbuahan-menurut-kecamatan-dan- jenis-buah-di-kabupaten-sampang2013-.html, pada 04 Juni 2019.

Dias Satria. (2009). Strategi Pengembangan Ekowisata Berbasis Ekonomi Lokal Dalam Rangka Program Pengentasan Kemiskinan di Wilayah Kabupaten Malang. "Journal of Indonesia AppliedEkonomics." Vol. 3 No. 1 (Fakultas Ekonomi Universitas Brawijaya)

Haidawati et al. (2016). Agrowisata kebun jambu kristal sebagai potensi ekonomi alternatif desa penyangga Taman Nasional Way Kambas, Lampung Timur. "Prosiding Seminar Nasional Pengabdian kepada Masyarakat - ISBN: 978602-0860-06-0 Lembaga Penelitian dan Pengabdian kepada Masyarakat Universitas Lampung."

Hernandi. (2018). Upaya Pengembangan Produk Unggulan, Diskumnaker Sampang Gelar Pelatihan Olahan Jambu Air, diakses dari https://radarbangsa.co.id/upayapengembangan-produk-unggulandiskumnaker-sampang-gelarpelatihan-olahan-jambu-airreporter-hernandi-k-s-sos-m-si/ pada pada tanggal 6 maret 2019

Iswahyudi, Emmy Darmawati and Sutrisno. (2015). Perancangan Kemasan Transportasi Buah Jambu Air (Syzygium aqueum) cv Camplong. "Jurnal Keteknikan Pertanian." Vol. 3, No.1. April

Jojok Dwirido Tjahjono, Maroeto at al. (2018). Kebijakan Dan Strategi Pengembangan Kawasan Agroekowisata Kecamatan Tuturdi Kabupaten Pasuruan, Jurnal: Peduli - Jurnal Ilmiah Pengabdian Pada Masyarakat, Vol. 2 No. 1.

Jojok Dwiridotjahjono et al. (2017). Pengembangan Agroekowisata Berbasis Perkebunan Kopi Rakyat Di Kecamatan Tutut Kebupaten 
Pasuruan., "Jurnal Ilmiah Pengapdian Kepada Masyarakat." vol 3 (2): 157-165 November 2017.

Kolter .(2006). Manajemen Pemasaran Edisi Kedua Belas Jilid 2. Jakarta: Indeks

M.R.G. Sayyed, M.S. Mansoori and R.G. Jaybhaye. (2013). SWOT analysis of Tandooreh National Park (NE Iran) for sustainable ecotourism, "Article." Proceedings of the International Academy of Ecology and Environmental Sciences, 2013, 3(4): 296-305.

Rahmat Hidayat. (2017). Strategi Pengembangan Ekowisata Berbasis Taman Bunga Pada Taman BungaNusantara Bogor, "Jurnal Ilmu-Ilmu Pertanian Agrika"
Volume 11 nomo1 Fakultas Pertanian Universitas Widyagama Malang.

Saga Ardian Gurindawangsa, Topowijono and Supriono. (2017). Analisis Strategi Pengembangan Produk Agrowisata (Studi Pada Desa Wisata Gubugklakah Kecamatan Poncokusumo Kabupaten Malang Jawa Timur). " Jurnal Administrasi Bisnis" vol. 51 No. 2 (Oktober 2017).

Spillane J. (1994). Ekonomi Pariwisata: Sejarah dan Prospeknya. Yogyakarta (ID): Kanisius.

I Ketut Sawena and I Gst Ngr Widyatmaja. (2010). Pengantar Dasar Ilmu Pariwisata. Desnpasar: Udayana University Press. 